\title{
Winter Oilseed Crops after Soybeans as Tools for Weed Management in Brazilian Savannah Cropping Systems
}

\author{
Germani Concenco ${ }^{1 *}$, Cesar Jose da Silva ${ }^{2}$, Michely Tomazi ${ }^{3}$, Rodolpho Freire Marques ${ }^{4}$, \\ Sabrina Alves dos Santos ${ }^{5}$, Maxwell Eliezer dos Santos Alves ${ }^{5}$, \\ Waggner Gomes Palharini' ${ }^{5}$, Air Lisboa Froes ${ }^{5}$, Denise Nascimento Fabris ${ }^{5}$ \\ ${ }^{1}$ Weed Science, Embrapa Western Agriculture, Dourados, Brazil \\ ${ }^{2}$ AgroEnergy, Embrapa Western Agriculture, Dourados, Brazil \\ ${ }^{3}$ Climate Change, Embrapa Western Agriculture, Dourados, Brazil \\ ${ }^{4}$ Federal University of Dourados, Dourados, Brazil \\ ${ }^{5}$ Embrapa Western Agriculture, Dourados, Brazil \\ Email: *germani.concenco@embrapa.br
}

Received 14 May 2014; revised 16 June 2014; accepted 2 July 2014

Copyright (C) 2014 by authors and Scientific Research Publishing Inc.

This work is licensed under the Creative Commons Attribution International License (CC BY).

http://creativecommons.org/licenses/by/4.0/

(c) (i) Open Access

\section{Abstract}

We aimed with this study to evaluate the potential of oilseed crops planted following soybean, in terms of their ability to inhibit the occurrence of weed species under Brazilian Savannah cropping systems. The long-term experiment was installed in 2010 at Dourados, MS, Brazil, and in completely randomized blocks design with five replications with $12 \times 24 \mathrm{~m}$ plot size. For three consecutive years $(2010 / 11,2011 / 12$ and $2012 / 13)$, soybeans were planted in all the area by October/November being harvested in February/March, when previously marked plots were planted in April with: (1) radish (Raphanus sativus); (2) rapeseed (Brassica napus); (3) crambe (Crambe abyssinica); (4) winter fallow-no plantation after soybeans. In all years the same crop was repeated at the same plots, with no crop rotation. Phytosociological characterization of weed species was carried out in winter (after oilseeds harvest), pre-planting and post-emergence of soybean for the three years. Relative abundance, frequency and dominance, as well as the importance value for each species, was obtained. Areas were also intra-characterized by the coefficients of Simpson, Shannon-Weiner and Shannon-Weiner's Evenness Proportion, and areas were compared for species dissimilarity with Jaccard's presence-only coefficient, by multivariate cluster analysis. Oilseed crops definitely contribute for sustainable weed management as a cultural tool. The most important oilseed crop weeds in the Savannah-like region of Brazil were Amaranthus hybridus, Richardia brasiliensis, Lepidium virginicum, Leonotis nepetifolia and Hybanthus parviflorus. After three years of repetitive crop succession, some weeds were selected, and rotation in Winter is advised at least every two or three years. 


\section{Keywords}

\section{Phytosociology, Diversity, Similarity, Sustainability}

\section{Introduction}

Soybean is one of the leading economical crops grown in Brazil, with about 27.7 million hectares planted in the 2013/2014 cropping season. Soybean yields in Brazil had significantly increased in the last decades, and current Brazilian average yield is $3035 \mathrm{~kg} \cdot \mathrm{ha}^{-1}$ [1]. Among the factors which limit crop yield, the occurrence of weed species can be highlighted as one of the most relevant facts [2].

Recent GMO technologies have aimed to employ herbicide resistance to soybean varieties and the weed infestation have drastically reduced in most fields with such technologies. Lack of Government regulation and Farmer's mismanagement of such technologies, however, led to the selection of weed species tolerant or resistant to the herbicides applied with these technologies [3]. The glyphosate-resistant Roundup Ready ${ }^{\circledR}$ soybean was widely used in Brazil for at least ten years, and currently Conyza bonariensis, C. canadensis, C. sumatrensis, Digitaria insularis, Lolium multiflorum [4] and Eleusine indica [5] are resistant to this herbicide, due to its extensive and almost uncontrolled use in Roundup Ready soybean. This abuse, moreover, resulted in the selection of weed species naturally more tolerant to glyphosate, namely Ipomoea spp., Richardia brasiliensis and Commelina benghalensis (tropical spiderwort), among others.

These facts have made researchers and companies retreat from the excessive reliability in GMO crops and has provided new possibilities to researches that regard integrated weeds management and integrated cropping systems [6] [7]. Researchers also started to notice that it is important to know the key traits of weed plants intended to be eliminated from the system, in order to develop management techniques that are efficient to the controlling of such species [8]. Phytosociological surveys started to gain relevance at the Weed Science field.

One of the main management practices which contribute to the reduction in weeds infestation is the continuous maintenance of straw on the soil surface [9], which limits weeds access to light. In addition, some plant species produce chemicals which usually exudate to soil through the root system, inhibiting germination and/or growth of other plant species. This phenomenon is called Allelopathy [10].

The intercrop of corn second crop (planted after soybeans) with Brachiaria ruziziensis was developed to allow the maintenance of a bold layer of mulching from the forage on soil after corn is harvested [9], thus soil would not be exposed to direct rainfall and sunlight when crop is not present. The crop succession soybean-corn $+B$. ruziziensis year after year, however, also started to select pests and weed species, urging for diversification at the second cropping season in Brazilian Savannah.

In addition, the demand for partial or total substitution of petroleum-based fuel oil for biofuels has become a topic of strategic security for many countries [11], aiming to meet both the increasing demand for energy and the new required limits for emission of gases responsible for the greenhouse effect [12]. Radish (Raphanus sativus), crambe (Crambe abyssinica) and rapeseed (Brassica napus) are promising for producing biofuels [13], being these winter oilseed crops good choices for a profitable second crop while keeping soil protected during fall/ winter; they can be planted later than corn, developing well even when planted after march $10^{\text {th }}$, which is a deadline for corn planting in the Brazilian Savannah [9].

Even being a profitable option to replace corn after soybean, the potential of these oilseed crops suppress the occurrence of weed species in areas where these are rotated with soybeans that need to be assessed. Oilseed crops could either demand additional herbicide application in the cropping system throughout the year for not suppressing weeds, or reduce herbicide demand supposing the most important weed species that are properly suppressed - the latter would be a highly desired side-effect.

This study aimed to evaluate the potential of oilseed crops planted following soybean, in terms of their ability to inhibit the occurrence of weed species under Brazilian Savannah cropping systems.

\section{Materials and Methods}

The long-term experiment was installed in 2010 under field conditions at Embrapa Western Agriculture, Dou-

\footnotetext{
*Corresponding author.
} 
rados city, state of Mato Grosso do Sul, Brazil, at coordinates $22^{\circ} 16^{\prime} \mathrm{S}$ and $54^{\circ} 49^{\prime} \mathrm{W}$ at $408 \mathrm{~m}$ above sea level. The trial was installed in completely randomized blocks design with five replications with plot size of $12 \times 24$ m.

For three consecutive years (2010/11, 2011/12 and 2012/13), soybeans were planted in all the area of the experiment by October/November, being harvested in February/March of the following year. After each soybean crop, each previously marked plot of the experiment was planted in April according to the treatment: (1) radish (Raphanus sativus); (2) rapeseed (Brassica napus); (3) crambe (Crambe abyssinica); (4) winter fallow-no plantation after soybeans. In all years the same crop was repeated at the same plots, with no crop rotation.

Soybean was planted, fertilized and managed according to the official Brazilian Recommendations for Soybean Crop in Cerrado (Savannah). Winter oilseed crops were planted in rows spaced in $0.4 \mathrm{~m}$, at plant densities of 32, 25 and 54 plants $\mathrm{m}^{-1}$ in the row, respectively for radish, rapeseed and crambe. Fertilization was accomplished by applying $347 \mathrm{~kg} \cdot \mathrm{ha}^{-1}$ of NPK 08-20-20 in the seeding furrow at planting every year. Pest control was necessary only at the initial growth stages, being accomplished by a single application of $35.2 \mathrm{~g} \cdot \mathrm{ha}^{-1}$ of thiamethoxam $+26.5 \mathrm{~g} \cdot \mathrm{ha}^{-1}$ lambda-cyhalothrin 20 - 30 days after planting. No further management (fertilization or pest control) was accomplished.

The amount of straw (in terms of dry mass) and its resultant percentage of soil covered were evaluated right after the harvest of winter crops every year. Data for these parameters were presented in histograms as a function of means and standard errors.

Phytosociological characterization of weed species was carried out every year for all areas, at three periods. "Winter" evaluations were accomplished right after harvest of the winter oilseed crops, by July/August; "PrePlanting" evaluations were accomplished about 30 days after chemical burndown (no residual herbicides were used) prior to planting soybean, usually by end of September or beginning of October; "Post-Emergence" evaluations occurred about 25 days after soybean emergence, in November. For that, the Random Quadrats method [14] was used and 5 areas of $0.50 \times 0.50 \mathrm{~m}$ were sampled in each plot (25 quadrats per treatment in each evaluation). All the emerged seedlings inside each quadrat were identified by species, collected and stored in paper bags, being dried in oven with continuous air circulation for posterior dry mass determination. Sampling precision was estimated as follows:

$$
\begin{gathered}
\text { Pr.De }=\frac{1}{s^{2}(D e)} \\
\text { Pr.Do }=\frac{1}{s^{2}(D o)}
\end{gathered}
$$

where $\operatorname{Pr} . D e=$ sampling precision based on density; $\operatorname{Pr} . D o=$ sampling precision based on dominance; $s^{2}(D e)=$ variance of sample density means; $s^{2}(D o)=$ variance of sample dominance means.

Estimations of relative density (based on number of individuals), relative frequency (based on the distribution of the species in the area) and relative dominance (based on the ability of each species to accumulate dry mass) were done for each species present. The Importance Value (I.V.), which ranks species in terms of importance within the studied area, was also determined [14] [15], with the following equations:

$$
\begin{array}{r}
r D e=\frac{I}{T I} \times 100 \\
r F r=\frac{Q}{T Q} \times 100 \\
r D o=\frac{D M}{T D M} \times 100 \\
I . V .=\frac{r D e+r F r+r D o}{3}
\end{array}
$$

where $r D e=$ relative density (\%); $r F r$ = relative frequency (\%); $r D o=$ relative dominance (\%); I.V. = importance value; $I=$ number of individuals of species $\mathrm{x}$ in the area $r ; T I=$ total number of individuals in the area $r$; $=$ number of quadrats assessed in area $r$ where species $x$ is present; $T Q=$ total number of quadrats assessed in area $r$; $D M=$ dry mass of individuals from species $x$ in the area $r$; TDM = total dry mass of weeds in the area $r$. 
At the phytosociological analysis, oilseed crops were pool analyzed against the area under fallow both as a function of cropping season (average of Winter + Pre-planting + Post-emergence) and evaluation season (average of $2011+2012+2013$ ), being presented for each area only the 10 most important weed species, according to the I.V., plus a discriminative analysis per crop (three-year average). Areas were also intra-characterized by the diversity coefficients of Simpson (D) and modified Shannon-Weiner $\left(H^{\prime}\right)$ [14], as well as by the Shannon- Weiner's Evenness Proportion (SEP) coefficients [16], as follows:

$$
\begin{gathered}
D=1-\frac{\sum n i \times(n i-1)}{N \times(N-1)} \\
H^{\prime}=\sum(p i \times \ln (p i)) \\
S E P=\frac{H^{\prime} \text { dominance }}{H^{\prime} \text { density }}
\end{gathered}
$$

where $D$ = diversity coefficient of Simpson; $H^{\prime}$ = diversity coefficient of Shannon-Weiner (based on density); $n i$ = number of individuals from species " $i$ ”; $N=$ total number of individuals in the sample; $p i=$ proportion of individuals in the sample from species “ $i$ ”; $S E P=$ Shannon-Weiner's Evenness Proportion; $H$ ' dominance = Shannon-Weiner's diversity based on biomass; $H^{\prime}$ density = Shannon-Weiner's diversity based on number of individuals.

After these analyses, areas were compared by Jaccard's presence-only similarity coefficient [14] in a way to estimate the current degree of weeds similarity between areas. Based on Jaccard's binary coefficient, areas were grouped by cluster analysis considering the qualitative trait only (presence or absence of the species), according to the dissimilarities obtained from the inverse of Jaccard's similarity matrix, as follows:

$$
\begin{gathered}
J=\frac{c}{a+b-c} \\
D i=1-J
\end{gathered}
$$

where $J=$ Jaccard's similarity coefficient; $a=$ number of plant species in area "a”; $b=$ number of plant species in area "b"; $c$ = number of plant species common to areas "a" and "b"; and $D i=$ dissimilarity.

Hierarchical grouping was determined from the distance matrix (dissimilarities) [12] by using the Unweighted Pair Group Method with Arithmethic Mean (UPGMA) method [17]. Grouping validation was accomplished by the cophenetic correlation coefficient, using the Pearson linear correlation between the cophenetic matrix and the original matrix of distances [18].

All analyses were run under the R Statistical Environment [19], using functions made available by the following additional packages: vegan, Hmisc, cluster and ExpDes. All formulas and procedures, both at sampling and description of the areas, as well as at species clustering, followed the requirements suggested by Barbour $e t$ al. [14] for synecological analyses.

\section{Results and Discussion}

Sampling precision proved most areas were precisely sampled, according to the demanded by Bordeau [20] and Goldsmith \& Harrison [21], who stated the variance of sample means increases as the number of sampled quadrats per area decreases. Barbour et al. [14] finally proposed the inverse of the variance (Equation (1)) as an indicator of precision; in this study, we considered a threshold level of " 1 " as the minimal precision accepted for a reliable sampling. Only dominance of rapeseed in Winter was considered not reliable (Table 1), being considered with restrictions in the further analysis.

The percentage of soil surface covered by straw resulting from the winter crops, as well as crop stubble dry mass, is shown in Figure 1. There was a direct relationship between the volume of dry mass produced by each crop/management and the respective the percentage of soil covered by this stubble (Figure 1) (Pearson correlation $=82.5 \%{ }^{*}$ ). On the other hand, there were only weak relationships both between the percentage of soil covered and the number of plants of weed species, and between soil covered and dry mass of weeds, which were not significant.

The number of weed individuals and dry mass of weeds per area was lower in areas planted with any oilseed crop compared to fallow areas, for all seasons (Figures 2(a)-(d)), except dry mass of weeds in crambe at 

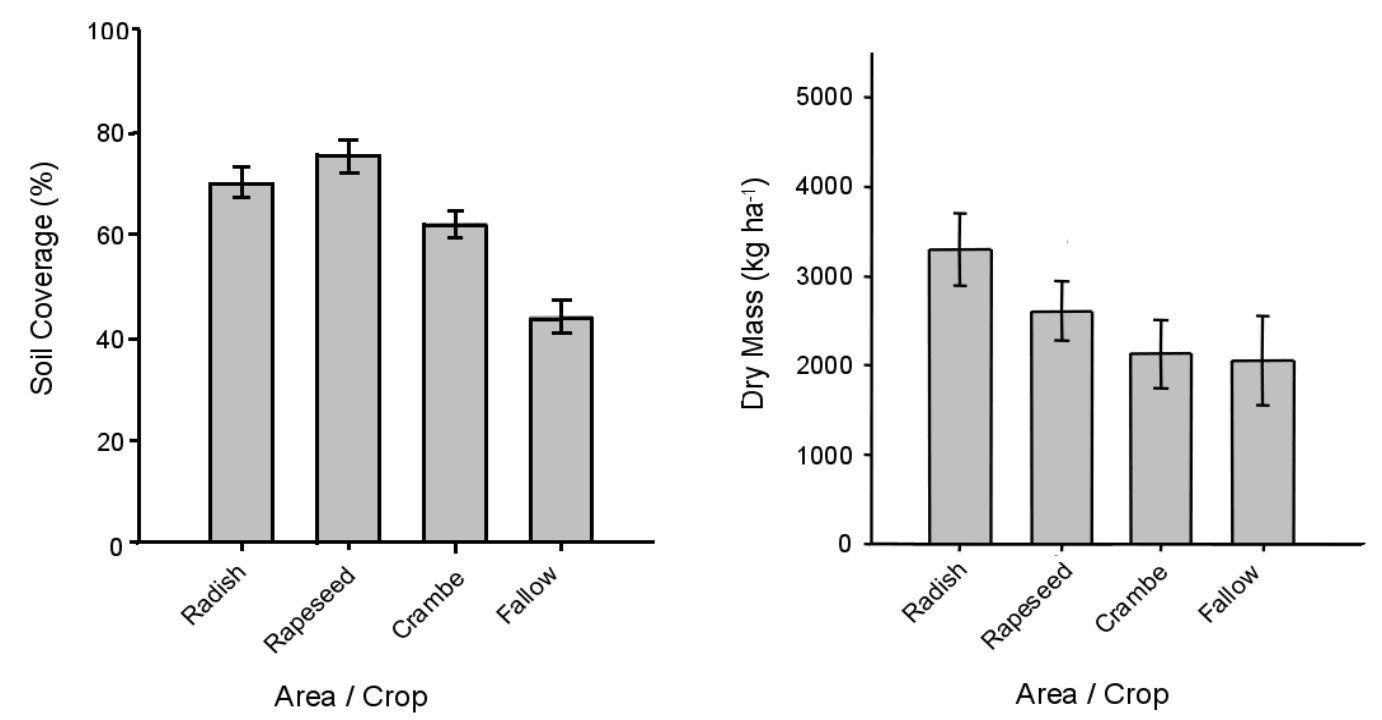

Figure 1. Soil covered (\%) and dry mass $\left(\mathrm{kg} \cdot \mathrm{ha}^{-1}\right)$ accumulated by winter oilseed crops, evaluated right after harvest. Embrapa Western Agriculture, Dourados, MS, Brazil, 2014.

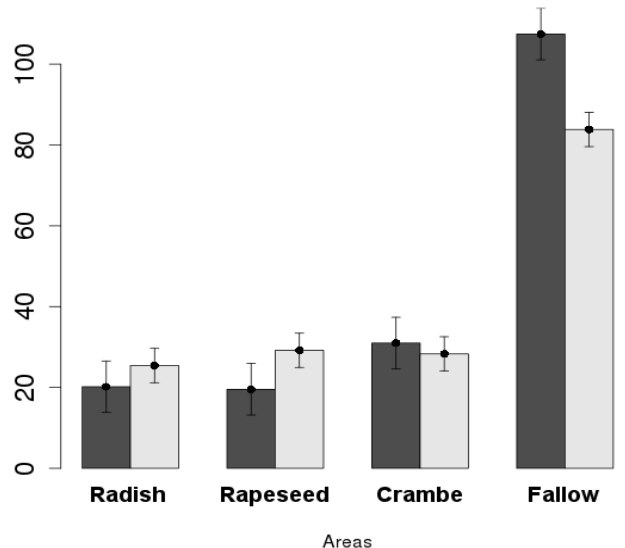

(a)

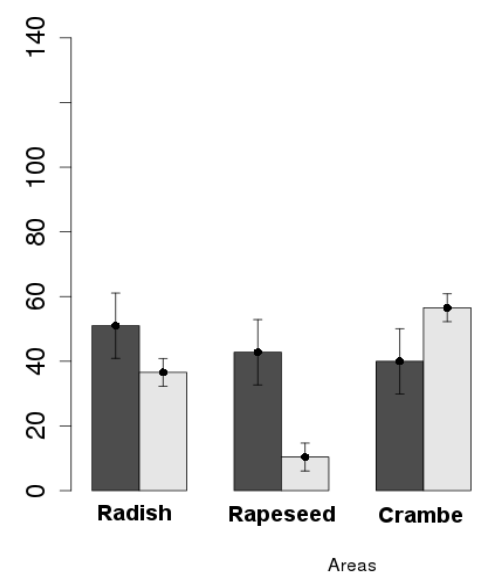

(c)

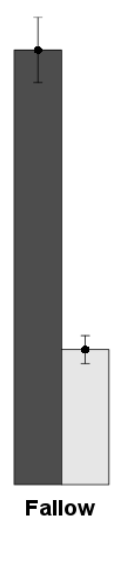

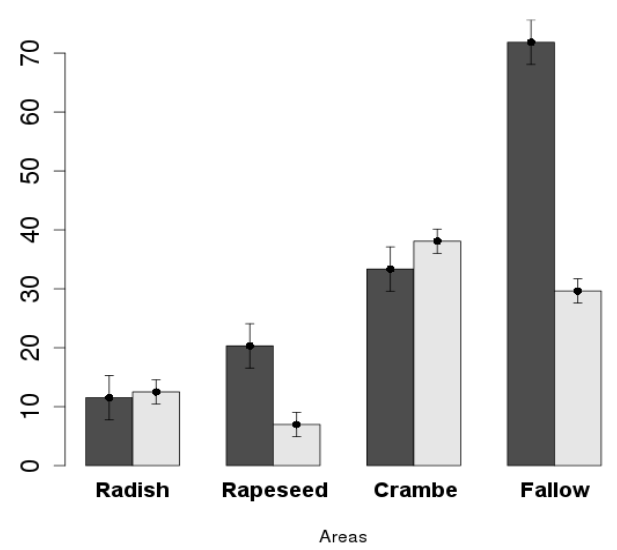

(b)

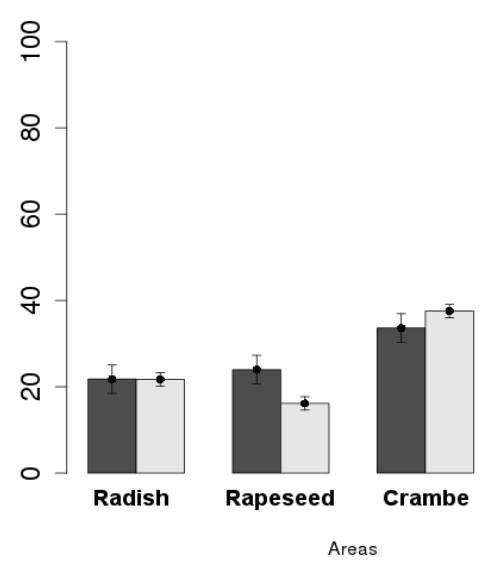

(d)

Figure 2. Number of plant individuals $\left(-\mathrm{m}^{-2}\right)$ and its respective dry mass $\left(-\mathrm{g} \cdot \mathrm{m}^{-2}\right)$ of weed species in Winter (a), pre-planting of soybean (b); early post-emergence of soybean (c) and season-pooled analysis (d). Data as average of three cropping seasons (2011/2012/2013). Embrapa Western Agriculture, Dourados, MS, Brazil, 2014. 
Table 1. Sampling precision as a function of season, crop and parameter evaluated. Embrapa Western Agriculture, Dourados, MS, Brazil, 2014.

\begin{tabular}{|c|c|c|c|c|}
\hline \multirow[b]{2}{*}{ Area } & \multicolumn{2}{|c|}{ Winter } & \multicolumn{2}{|c|}{ Pre-Planting } \\
\hline & Pr.De & Pr.Do & Pr.De & Pr.Do \\
\hline Radish & 141 & 19 & 1237 & 665 \\
\hline Rapeseed & 1134 & 0.8 & 19 & 493 \\
\hline Crambe & 476 & 51 & 192 & 217 \\
\hline \multirow[t]{2}{*}{ Fallow } & 148 & 152 & 37 & 62 \\
\hline & \multicolumn{2}{|c|}{ Post-Emergence } & \multicolumn{2}{|c|}{ Pooled } \\
\hline Area & Pr.De & Pr.Do & Pr.De & Pr.Do \\
\hline Radish & 196 & 173 & 585 & 151 \\
\hline Rapeseed & 51 & 1054 & 32 & 523 \\
\hline Crambe & 3105 & 132 & 285 & 349 \\
\hline Fallow & 36 & 54 & 152 & 61 \\
\hline
\end{tabular}

Precision was obtained as 1/(variance of sample means), according to Barbour et al. [14], based on 25 sampled quadrats per area. Pr.De = sampling precision based on density; Pr.Do = sampling precision based on dominance.

pre-planting (Figure 2(b)). In Winter (Figure 2(a)), about 27 plants $\cdot \mathrm{m}^{-2}$ were observed as average of the winter crops while 108 plants $\cdot \mathrm{m}^{-2}$ were observed at the fallow area, immediately after oilseed crops harvest. The same was observed for dry mass, where $30 \mathrm{~g} \cdot \mathrm{m}^{-2}$ were observed in the oilseed crop areas against $83 \mathrm{~g} \cdot \mathrm{m}^{-2}$ at the fallow area. This translated to about $25 \%$ and $36 \%$ of the infestation, respectively for number of weed individuals and dry mass accumulated, for areas planted with oilseed crops compared to areas under fallow (Figure 2(a)).

At the pre-planting of soybean (Figure 2(b)), infestation was kept at low levels in areas previously planted with radish and rapeseed, but crambe straw failed to suppress weeds at the same level. While 12 and 21 plants $\cdot \mathrm{m}^{-2}$ were observed for areas previously planted with radish and rapeseed, respectively, at the area with crambe 32 plants $\cdot \mathrm{m}^{-2}$ were reported, against 71 plants $\cdot \mathrm{m}^{-2}$ at the fallow area. Dry mass presented similar behavior, except for rapeseed, where plants emerged but did not grow at the same rate of the ones observed at radish and crambe areas (Figure 2(b)).

All oilseed crops were able to inhibit weeds emergence and establishment during winter, when crops were present, but at the pre-planting crambe did not perform well. This may be due to two reasons: 1 ) both soil covered and crop dry mass accumulated at the post-harvest of oilseed crops were smaller for crambe compared to radish or rapeseed, in part because this crop has shorter cycle thus being harvested about 60 days in advance (Figure 1), and 2) the allelopathic effect of radish and rapeseed in suppressing weeds may be more pronounced than crambe. In fact, Uygur et al. [22] reported that extracts of radish completely inhibited the germination of 4 crop plants and 11 weed species. Although radish accumulate greater dry mass than crambe (Figure 1), its ability to suppress weeds (Figure 2) was higher than what would be attributed to the differential dry mass accumulation, being attributed to the allelopathic effect of radish, as previously reported.

At post-emergence of soybean (Figure 2(c)), there was still effects of the winter management on the level of weeds infestation, where areas previously planted with oilseed crops were always less infested than the area under fallow, and similar among them in terms of number of weed individuals per area. Dry mass of weeds, however, differed not only from the fallow but also among oilseed crops (Figure 2(c)). Weed dry mass was about 13, 37 and $46 \mathrm{~g} \cdot \mathrm{m}^{-2}$, respectively at areas previously planted with rapeseed, radish and crambe. Although weed dry mass accumulation was not pronounced at the fallow area by the time of evaluation-probably due to the coupled effect of soybean shading and glyphosate application, the high number of individuals at this treatment indicated that weeds were smaller than the observed at the areas under oilseed crops, but the latent infestation was high.

The season-pooled analysis (Figure 2(d)) showed that radish and rapeseed performed better than crambe in inhibiting the occurrence of weed species, and winter fallow should not be adopted in areas where soybeans are to be cropped. Although infestation at the area with crambe was higher, this crop was still able to suppress in 
more than $50 \%$ the occurrence of weeds compared to fallow, which also resulted in smaller weed dry mass per area (Figure 2(d)).

When number of weeds and its respective dry mass are compared in Pre-Planting (Figure 2(b)) and PostEmergence (Figure 2(c)) of rapeseed, it is possible to infer that weeds were smaller compared to the ones present at the other areas, thus with delayed emergence. This delayed emergence of weeds in rapeseed is most probably a consequence of the time needed for seeds forced to a quiescent or dormant state to restart their metabolism and allow germination [23].

The longer cycle of rapeseed compared to radish and crambe could also participate in this delayed emergence of weeds, but evaluations where plants took longer to germinate were conducted at pre-planting and post-emergence of soybean, where the effect observed on weeds could be more reliably attributed to the rapeseed mulching left on soil than to rapeseed cycle. In practical terms, weed infestation at this area would be less severe due to the time needed for plants of weed species to establish themselves, allowing crop to have good advantage in development, causing shading and suppressing weeds [24] [25].

The evolution of weed occurrence from the assembly of the trial (Table 2, upper section) showed that species changed from the first to the third year of the trial both for the oilseed crops and the fallow area. At the areas with oilseed crops, in $2011 R$. brasiliensis and A. hybridus were the most important weed species, which accounted for 36.4\% of the Importance Value (IV); in 2012 part of the IV from $R$. brasiliensis was shifted to A. hybridus, but both were still the most important weed species. At the third year of the experiment, $R$. brasiliensis and $L$. virginicum were the most important ones.

While R. brasiliensis was important all throughout the trial, accounting for $16.1 \%-32.6 \%$ of the IV, L. virginicum started as a weak weed species which jumped from IV $=0.3 \%$ at the first year to IV $=26.7 \%$ at the third year (Table 2). This greatly highlights weed management in areas often planted with oilseed crops should focus on controlling these two weeds if they are present, besides A. hybridus, H. parviflorus and L. nepetifolia which were also important in years where climatic conditions favored its occurrence. L. nepetifolia (klip dagga) is a common, but low competitive weed, which is usually either easily controlled with herbicides or suppressed by other plant species.

For the area under fallow (Table 2), $\mathrm{H}$. parviflorus was responsible for about $15 \%$ of the IV at the first and third years, while $R$. brasiliensis also ranged from $16.1 \%$ to $25.7 \%$ in IV. At the first year infestation was more balanced, with five weed species presenting IV of about $10 \%-15 \%$; at the third year, however, L. nepetifolia and $R$. brasiliensis suppressed most weed species, representing together $53.6 \%$ of the overall infestation in the area under fallow (Table 2).

Besides the I.V., H. parviflorus, L. nepetifolia, L. virginicum and R. brasiliensis are highlighted for its numerous offspring (De), each species solely representing, in most cases, more than $20 \%$ of the individuals accounted at the experiment (Table 2). In the same way, A. hybridus, L. virginicum and $R$. brasiliensis were the most vigorous weed species as their Dominance (Do) was often higher than 20\% (Table 2).

When the evaluation season is considered (Table 2, lower section), it is noted that the most important weed species in the system were present all throughout the year. For the area grown with oilseed crops, $R$. brasiliensis was the most important one from Winter to Post-Emergence, followed by A. hybridus in Winter and PostEmergence. At the intermediary assessment, L. virginicum surpassed A. hybridus in importance. For the area under fallow, $R$. brasiliensis was also the most important and persistent weed species, but contrary to the observed for the oilseed areas, $L$. nepetifolia surpassed L. virginicum and A. hybridus as the second most important species in Winter and Pre-Planting, and H. parviflorus was the second most important one in Post-Emergence (Table 2). Overall, there was no weed species most present in a certain season; important weed species were the ones with year-round occurrence (Table 2).

Mas et al. [26] observed that weed communities after five or more years of no-till glyphosate-tolerant soybean cropping systems had: (i) higher relative abundance of perennials (52.1\% versus $31.7 \%)$, and (ii) higher relative abundance of dicotyledons (66.3\% versus 38.5\%) than the weed communities of fields with $<5$ years of no-till. At this study, a predominance of broadleaved weeds was also observed (Table 2), although the absolute level of infestation was reduced in areas planted with winter oilseed crops (Figure 2).

When areas were compared among them, as average of three years with three assessments per year (Table 3), $R$. brasiliensis was reported as the most important weed in crambe following $L$. virginicum, and the second most important in radish, rapeseed and fallow areas. A. hybridus was the most important species in radish and the third most important in rapeseed, crambe and fallow. H. parviflorus, reported as the most important one in rape 
Table 2. Phytosociological parameters of the 10 most important weed species, as a function of year (average of Winter/Pre-Planting/Post-Emergence evaluations), and cropping season (average of years 2011/2012/2013). Embrapa Western Agriculture, Dourados, MS, Brazil, 2014.

\begin{tabular}{|c|c|c|c|c|c|c|c|c|c|c|c|c|c|c|c|c|c|c|c|c|c|c|c|c|}
\hline \multirow[b]{2}{*}{ Weed Species } & \multicolumn{4}{|c|}{$\begin{array}{l}\text { Winter Oilseed } \\
\text { Crops }\end{array}$} & \multicolumn{4}{|c|}{ Winter Fallow } & \multicolumn{4}{|c|}{$\begin{array}{l}\text { Winter Oilseed } \\
\text { Crops }\end{array}$} & \multicolumn{4}{|c|}{ Winter Fallow } & \multicolumn{4}{|c|}{$\begin{array}{l}\text { Winter Oilseed } \\
\text { Crops }\end{array}$} & \multicolumn{4}{|c|}{ Winter Fallow } \\
\hline & De & Fr & Do & I.V. & De & Fr & Do & I.V. & De & Fr & Do & I.V. & De & Fr & Do & I.V. & De & Fr & Do & I.V. & De & Fr & Do & I.V. \\
\hline
\end{tabular}

$\begin{array}{lllllllllllllllllllllllllll}\text { A. deflexus } & 17.7 & 8.1 & 19.1 & 15.0 & 3.9 & 5.6 & 14.1 & 7.9 & 6.9 & 7.3 & 4.4 & 6.2 & 0.4 & 1.7 & 0.8 & 0.9 & 0.2 & 0.7 & 0.0 & 0.3 & 0.7 & 5.2 & 9.4 & 5.1\end{array}$

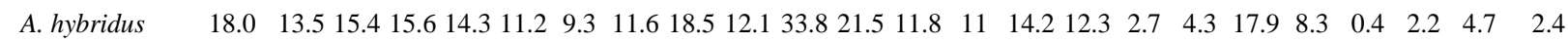

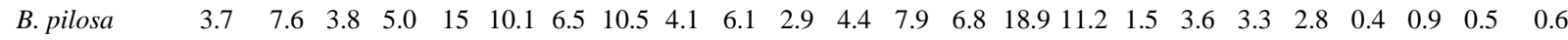

$\begin{array}{lllllllllllllllllllllllll}\text { C. benghalensis } & 2.8 & 3.8 & 1.6 & 2.7 & 1.7 & 6.7 & 1.6 & 3.3 & 2.9 & 4.0 & 4.0 & 3.7 & 1.9 & 7.6 & 6.4 & 5.4 & 0.0 & 0.0 & 0.0 & 0.0 & 0.9 & 4.7 & 1.5 & 2.4\end{array}$

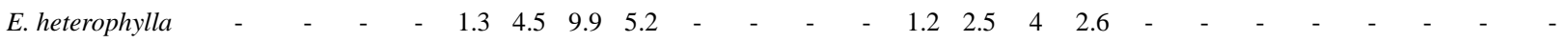

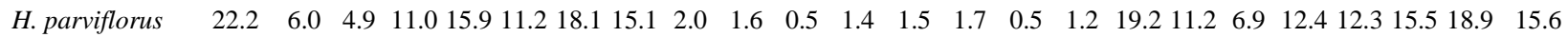

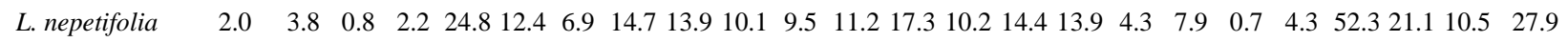

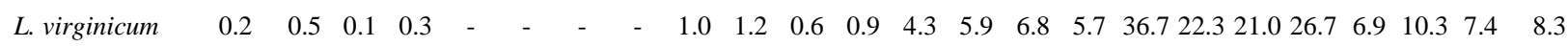

R. brasiliensis $\quad 16.3 \quad 21.124 .920 .8 \quad 7.412 .320 .313 .417 .217 .713 .216 .111 .712 .710 .311 .528 .231 .738 .132 .621 .321 .134 .8 \quad 25.7$

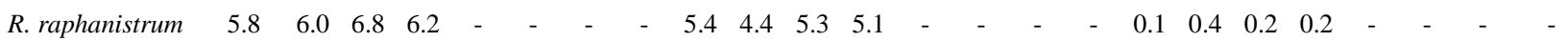

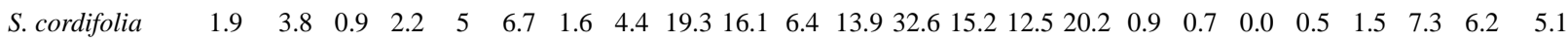

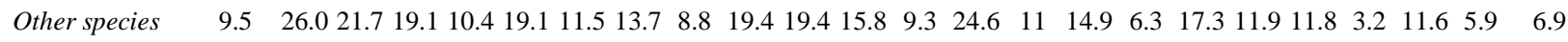

\begin{tabular}{|c|c|c|c|c|c|c|c|c|c|c|c|c|c|c|c|c|c|c|c|c|c|c|c|c|}
\hline A. deflexus & 14.8 & 6.8 & 14.4 & 12 & 2.0 & 5.9 & 6.3 & 4.7 & 5.8 & 6.8 & 5.5 & 6.1 & 1.0 & 5.6 & 7.6 & 4.7 & - & - & - & - & - & - & - & - \\
\hline A. hybridus & 4.6 & 7.3 & 32.8 & 14.9 & 1.8 & 4.3 & 11.8 & 5.9 & 3.1 & 4.4 & 13.8 & 7.1 & 0.8 & 3.5 & 5.9 & 3.4 & 30.9 & 19.1 & 21.7 & 23.9 & 18.6 & 13.9 & 12.7 & 15.1 \\
\hline B. pilosa & 3.9 & 5.5 & 2.8 & 4.1 & 1.8 & 3.7 & 15.9 & 7.1 & 2.2 & 5 & 3.7 & 3.6 & 0.7 & 1.4 & 0.6 & 0.9 & 2.7 & 6.1 & 3.5 & 4.1 & 15.2 & 9.3 & 8.4 & 11.0 \\
\hline C. benghalensis & 1.3 & 3 & 4.3 & 2.8 & 1.6 & 5.9 & 5.9 & 4.5 & - & - & - & - & 0.9 & 4.2 & 1.1 & 2.1 & 4.2 & 5.1 & 1.5 & 3.6 & 1.3 & 8.3 & 1.3 & 3.7 \\
\hline H. parviflorus & 2.3 & 4.3 & 0.3 & 2.3 & 5.8 & 7.5 & 2.4 & 5.2 & 21.5 & 8.9 & 5.7 & 12.1 & 14.6 & 15.4 & 17.6 & 15.8 & 21.4 & 5.5 & 6.5 & 11.1 & 12.4 & 11.1 & 24.5 & 16.0 \\
\hline L. nepetifolia & 7.9 & 10.3 & 5.4 & 7.9 & 38.6 & 18.1 & 14.2 & 23.6 & 10.4 & 10.1 & 6.1 & 8.8 & 48.0 & 18.9 & 7.8 & 24.9 & 0.3 & 1.1 & 0.4 & 0.6 & 28.1 & 10.2 & 9.2 & 15.8 \\
\hline L. virginicum & 23 & 14.9 & 7.1 & 15 & 7.2 & 10.1 & 7.6 & 8.3 & 20.9 & 11.2 & 8.2 & 13.4 & 6.2 & 8.4 & 4.6 & 6.4 & - & - & - & - & - & - & - & - \\
\hline R. brasiliensis & 23.9 & 24.7 & 8.3 & 19.1 & 19.2 & 18.1 & 14.3 & 17.2 & 23.4 & 25.4 & 34.1 & 27.6 & 20.0 & 19.6 & 27.8 & 22.5 & 16.3 & 21.2 & 35.1 & 24.3 & 7.4 & 12.0 & 28.2 & 15.9 \\
\hline R. raphanistrum & - & - & - & - & - & - & - & - & 0.3 & 0.7 & 0.5 & 0.5 & 0.1 & 0.7 & 0.4 & 0.4 & 10.9 & 10.6 & 17.9 & 13.1 & 4.2 & 5.6 & 6.9 & 5.5 \\
\hline S. cordifolia & 12.8 & 8.5 & 2.6 & 7.9 & 17.2 & 9.6 & 7.3 & 11.4 & 3.8 & 6.1 & 5.6 & 5.2 & 2.3 & 8.4 & 15.3 & 8.7 & 3.3 & 6.1 & 0.1 & 3.2 & 6.6 & 10.2 & 3.3 & 6.7 \\
\hline Other species & 5.5 & 14.5 & 22 & 14.1 & 4.9 & 17.1 & 14.2 & 12.1 & 8.6 & 21.5 & 16.8 & 15.6 & 5.3 & 14.1 & 11.4 & 10.3 & 10.1 & 25.3 & 13.2 & 16.2 & 6.3 & 19.4 & 5.6 & 10.4 \\
\hline
\end{tabular}

Winter Oilseed Crops: radish, crambe and rapeseed areas; Winter Fallow: planted with soybean, no crops in winter; De = density; Fr = frequency; Do = dominance; I.V. = importance value; $(-)$ = species absent from the area. Evaluations: "Winter" = right after harvest of the winter oilseed crops, by July/August; "Pre-Planting" = about 30 days after no-residual chemical burndown prior to planting soybean, by September/October; "Post-Emergence" = about 25 days after soybean emergence, in November.

seed, is not a traditional weed species but its importance is increasing at the Center-West region of Brazil. This species is not efficiently controlled by the glyphosate or 2, 4-D, the main burndown herbicides used prior to planting soybean.

A. hybridus and $R$. brasiliensis are reported as the most dominant species in radish, rapeseed and crambe areas, highlighting its ability to accumulate dry mass and compete for physical space with the crop. Both species were also the ones with the highest densities in radish, while $H$. parviflorus, $L$. virginicum and L. nepetifolia were the densest ones, respectively in rapeseed, crambe and fallow areas (Table 3). 
Table 3. Phytosociological parameters of the 10 most important weeds infesting winter oilseed crops and fallow, as average of three years (2011/2012/2013) with three evaluations per year (Winter, Pre-planting and Post-emergence of soybean). Embrapa Western Agriculture, Dourados, MS, Brazil, 2014.

\begin{tabular}{|c|c|c|c|c|c|c|c|c|c|c|c|c|c|c|c|c|}
\hline \multirow[b]{2}{*}{ Species } & \multicolumn{4}{|c|}{ Radish } & \multicolumn{4}{|c|}{ Rapeseed } & \multicolumn{4}{|c|}{ Crambe } & \multicolumn{4}{|c|}{ Winter Fallow } \\
\hline & De & Fr & Do & I.V. & De & Fr & Do & I.V. & De & Fr & Do & I.V. & De & Fr & Do & I.V. \\
\hline A. deflexus & 7.6 & 0.5 & 5.0 & 4.4 & 6.2 & 0.1 & 2.9 & 3.0 & 7.7 & 2.9 & 11.9 & 7.5 & 1.2 & 2.1 & 5.8 & 3.0 \\
\hline A. hybridus & 24.0 & 11.3 & 32.6 & 22.6 & 5.6 & 6.4 & 20.7 & 10.9 & 8.5 & 4.6 & 20 & 11.0 & 5.6 & 9.3 & 10.5 & 8.5 \\
\hline B. pilosa & - & - & - & - & - & - & - & - & 3.2 & 0.7 & 3.7 & 2.5 & 4.7 & 0.5 & 11.1 & 5.4 \\
\hline E. colona & - & - & - & - & 0.2 & 5.5 & 8.0 & 4.5 & - & - & - & - & - & - & - & - \\
\hline E. indica & 0.3 & 16.1 & 0.6 & 5.7 & - & - & - & - & 0.2 & 6.2 & 0.1 & 2.1 & - & - & - & - \\
\hline E. hieraciifolius & - & - & - & - & 0.1 & 12.8 & 0.1 & 4.3 & - & - & - & - & 0.1 & 16.4 & 0.1 & 5.5 \\
\hline H. parviflorus & 6.4 & 4.3 & 2.8 & 4.5 & 40.6 & 5.5 & 12.0 & 19.4 & 2.0 & 6.2 & 0.4 & 2.9 & 10.3 & 4.3 & 9.2 & 7.9 \\
\hline I. nil & 0.3 & 23.1 & 0.1 & 7.8 & 0.1 & 26.0 & 0.1 & 8.7 & 0.9 & 23.2 & 3.7 & 9.3 & 0.3 & 17.1 & 0.1 & 5.8 \\
\hline L. nepetifolia & 6.6 & 5.4 & 4.8 & 5.6 & 8.1 & 13.2 & 4.9 & 8.7 & 5.4 & 2.3 & 4.0 & 3.9 & 39.1 & 10.9 & 11.9 & 20.6 \\
\hline L. sibiricus & - & - & - & - & 0.6 & 0.1 & 15.2 & 5.3 & - & - & - & - & - & - & - & - \\
\hline L. virginicum & 6.1 & 1.6 & 0.7 & 2.8 & - & - & - & - & 32.2 & 0.3 & 11.0 & 14.5 & 5.1 & 0.1 & 5.8 & 3.7 \\
\hline R. raphanistrum & 8.4 & 1.1 & 11.6 & 7.0 & - & - & - & - & - & - & - & - & - & - & - & - \\
\hline R. brasiliensis & 21.7 & 0.1 & 21.3 & 14.3 & 19.0 & 0.1 & 15.9 & 11.7 & 23.1 & 0.7 & 27.9 & 17.2 & 16.6 & 0.1 & 19.6 & 12.1 \\
\hline S. cordifolia & 10.6 & 0.1 & 3.1 & 4.6 & 8.2 & 0.5 & 5.6 & 4.8 & - & - & - & - & 9.7 & 0.1 & 8.7 & 6.2 \\
\hline S. rhombifolia & - & - & - & - & - & - & - & - & 0.1 & 17.0 & 0.1 & 5.7 & - & - & - & - \\
\hline Other species & 7.9 & 36.6 & 17.7 & 20.7 & 11.7 & 30.1 & 14.8 & 18.9 & 16.8 & 36.0 & 17.4 & 23.4 & 7.4 & 39.4 & 17.2 & 21.3 \\
\hline
\end{tabular}

$\mathbf{D e}=$ density; $\mathbf{F r}=$ frequency; Do = dominance; I.V. = importance value; $(-)=$ species was absent from the area.

The diversity coefficient of Simpson (D) quantifies, in simple terms, the probability of two individuals randomly collected in the same area to be from the same species [14]. In Winter, D showed a most homogeneous group of areas in terms of diversity, while $\mathrm{H}^{\prime}$ discriminated two groups, with radish and rapeseed into the first group, and crambe and fallow into the second (Table 4). The diversity coefficient of Shannon-Weiner ( $\mathrm{H}^{\prime}$ ), on the other hand, derives from the Theory of the Information and sometimes confuses diversity with richness of species [14]. This difference, although not highly remarkable, shows that the overall group of important weeds was mostly composed by the frequent species, as H' was greatly changed while no correspondent shifts in infestation were noticed in the phytosociology (Table 2 and Table 3).

At Pre-Planting, both D and H' reported rapeseed area as the one with the lowest diversity in terms of plant species (Table 4), which may be due to the longer cycle of rapeseed compared to radish and crambe, whose residues were later deposited lasting longer and covering soil more efficiently (Figure 1).

At Post-Emergence of soybean, both coefficients agreed while forming two groups in terms of species diversity: the first included radish and rapeseed while the second was represented by crambe and fallow areas (Table 4). We hypothesize that the higher allelopathic effect attributed to radish and rapeseed [27] compared to crambe, may be one of the responsible for such results; in addition, the longer cycle of rapeseed compared to radish and crambe contributes to its higher mulching, once it is harvested later than the others. This demonstrates that the beneficial effects of the winter oilseed crops last longer into summer helping to reduce weeds occurrence. 
Table 4. Diversity and stress coefficients of areas as a function of crop and evaluation season (average of 2011/2012/2013). Embrapa Western Agriculture, Dourados, MS, Brazil, 2014.

\begin{tabular}{|c|c|c|c|c|c|c|}
\hline \multirow[b]{2}{*}{ Area } & \multicolumn{3}{|c|}{ Winter } & \multicolumn{3}{|c|}{ Pre-Planting } \\
\hline & D & $\mathbf{H}^{\prime}$ & SEP & D & $\mathbf{H}^{\prime}$ & SEP \\
\hline Radish & 0.85 & 2.03 & 0.68 & 0.86 & 2.28 & 1 \\
\hline Rapeseed & 0.84 & 2.18 & 0.97 & 0.64 & 1.47 & 1.25 \\
\hline Crambe & 0.71 & 1.67 & 1.17 & 0.79 & 2.06 & 1.07 \\
\hline \multirow[t]{2}{*}{ Fallow } & 0.77 & 1.89 & 1.29 & 0.7 & 1.65 & 1.33 \\
\hline & \multicolumn{3}{|c|}{ Post-Emergence } & \multicolumn{3}{|c|}{ Pooled } \\
\hline Area & D & $\mathbf{H}^{\prime}$ & SEP & $\mathbf{D}$ & $\mathbf{H}^{\prime}$ & SEP \\
\hline Radish & 0.71 & 1.59 & 1.06 & 0.86 & 2.25 & 0.99 \\
\hline Rapeseed & 0.61 & 1.38 & 1.16 & 0.78 & 1.97 & 1.19 \\
\hline Crambe & 0.84 & 2.28 & 0.74 & 0.82 & 2.27 & 1.02 \\
\hline Fallow & 0.84 & 2.08 & 0.96 & 0.79 & 2.03 & 1.24 \\
\hline
\end{tabular}

D = Simpson; H' = Shannon-Weiner; SEP = Shannon-Weiner's Evenness Proportion. Evaluations: "Winter" = right after harvest of the winter oilseed crops, by July/August; "Pre-Planting” = about 30 days after no-residual chemical burndown prior to planting soybean, by September/October; "Post-Emergence" = about 25 days after soybean emergence, in November; "Pooled" = Winter + Pre-planting + Post-emergence.

According to Correia \& Durigan [28], diversity is not directly related to higher infestation levels, and we found that to be true by comparing data in Figure 2 and Table 4. As both diversity coefficients are weighted not only by the number of species but also by the balancing in the number of individuals from each species [14], one can infer the allelopathic potential often attributed to radish and rapeseed will be even more positive to the cropping system if they are able to inhibit the germination or emergence of the main weed species previously nominated, which should be verified in further studies.

The season-pooled analysis reported a single group of diversity among crops according to D, while H' removed rapeseed from the homogeneous group due to a lower diversity coefficient (Table 4). This lower diversity pointed out by H' could mean rapeseed is more efficient in inhibiting rare species compared to the most frequent ones, but the equivalent V.I. attributed to "Other species”, for all areas (Table 3) does no support this hypothesis; so, weed suppression caused by rapeseed in the cropping system throughout the year is most probably effective on all weed species at similar levels, which resulted in the lowest overall infestation (Figure 2(d)).

The Shannon-Weiner's Evenness Proportion (SEP) is able to evaluate trends of stress in a given environment over time, and as its relation with the Difference in Area by Percent (DAP) is log-linear [16], the cropping system is likely to be as stressed as the SEP grows. In Winter there was a trend for areas often planted with radish or rapeseed to be less stressed than the others, with smaller selection pressure (Table 4). This trend was moderately observed in the Pre-Planting assessment being almost diluted at Post-Emergence. In the pooled analysis, however, there is indication that areas grown with radish and crambe may be under less intensive stress, thus contributing for selection of less specialized weed species. The general behavior of rapeseed was considered as intermediary between radish/crambe and fallow, the less and most stressed production fields, respectively, in terms of weeds selection (Table 4).

The cluster analysis showed the nesting pattern for areas, according to their levels of similarity (Figure 3). The clustering tree obtained by the UPGMA method was validated for Winter and Pooled Analysis, with respective cophenetic correlation coefficients equal to $99 \%$ and $98 \%$. Both at Pre-Planting and Post-Emergence, the cophenetic coefficient was equal respectively $0.75 \%$ and $0.78 \%$, which was considered not sufficient for reliability thus being discarded (data not shown).

Both valid nesting patterns grouped radish and crambe at $29 \%$ and $40 \%$ dissimilarity, respectively for Winter and year-round (Pooled) analysis (Figure 3). In Winter, rapeseed and fallow areas were not nested, consisting in two distinct groups with a single component each one; at the pooled analysis (Figure 3(b)), the fallow area was 


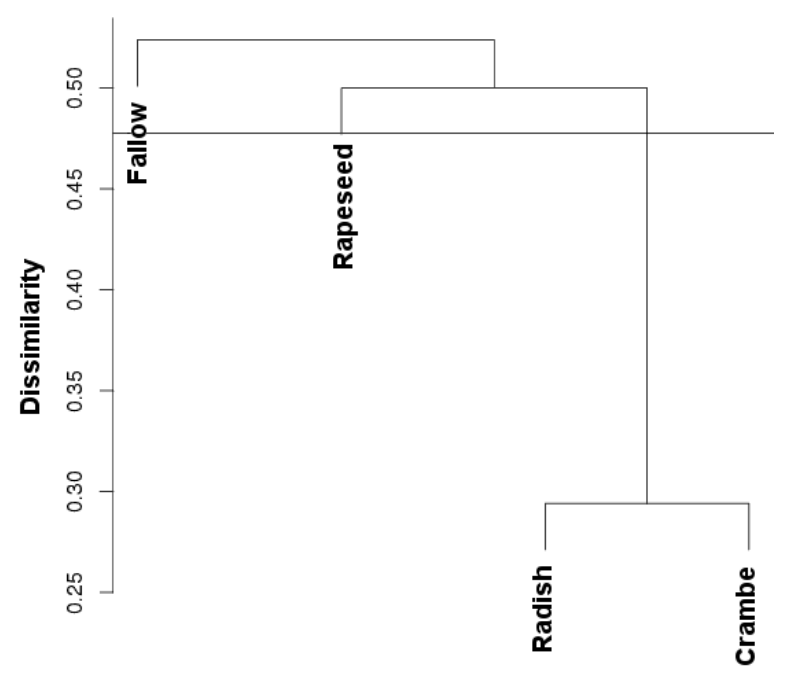

C.C. $=0.99$ *

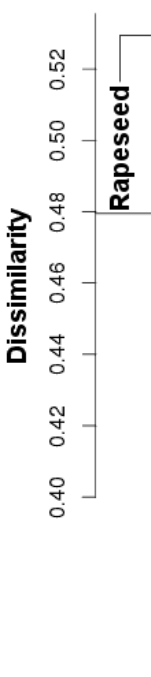

C.C. $=0.98$ *

(a)

(d)

Figure 3. Cluster analysis by dissimilarity of weed species in areas submitted to distinct winter managements for three years. (a) = Winter (evaluation right after harvest of the winter oilseed crops, by July/August); (b and c) = evaluations at pre-planting and post-emergence of soybean; data not shown and not considered due to a low cophenetic coefficient; (d) = pooled analysis (Winter + Pre-planting + Post-emergence). Distances were found by using the inverse of Jaccard's coefficient, and grouping was accomplished by the UPGMA method. Embrapa Western Agriculture, Dourados, MS, Brazil, 2014.

grouped with radish and crambe, while rapeseed was separately classified. The nesting pattern (Figure 3) is according to the observed for the SEP analysis (Table 4), where radish and crambe were considered, in general terms, in the less stress-prone areas in terms of weed selection.

Overall, oilseed crops may constitute an economically viable alternative for rotation with the intercrop corn + Brachiaria, which is planted after soybean in most areas of Brazilian Savannah (Cerrado), and definitely they contribute for a more sustainable weed management as a cultural tool. The most important weed species in cropping systems involving oilseed crops (radish, rapeseed or crambe) in the Savannah-like region of Brazil, were Amaranthus hybridus, Richardia brasiliensis, Lepidium virginicum, Leonotis nepetifolia and Hybanthus parviflorus; thus, any weed control practice applied to the field should focus on and be efficient on these species. After three years of repetitive crops successions, although no serious species selection was noticed, there were some weeds which started to be selected, and rotation in Winter of oilseed crops for the intercrop corn $+B r a-$ chiaria is advised at least every two or three years of cultivation. This is most critical for areas planted with rapeseed after soybean, since this area was more stressed for weed species selection compared to areas planted with radish and crambe.

\section{Acknowledgements}

The authors would like to thank MCT/FINEP (Research Agreement \# 01.08.0565-00) and FUNDECT (Approval term \# 00154/10) for the financial support granted for this research.

\section{References}

[1] CONAB (2014) Acompanhamento da Safra Brasileira de Grãos. 5º Levantamento, 1, 1-69.

[2] Silva, A.F., Galon, L., Aspiazú, I., Ferreira, E.A., Concenço, G. Ramos Jr., E.U. and Rocha, P.R.R. (2013) Weed Management in the Soybean Crop. In: El-Shemy, H.A., Ed., Soybean-Pest Resistance, Intech, Rijeka, 85-112. http://dx.doi.org/10.5772/54596

[3] Trezzi, M.M., Nunes, A.L. and Portes, E.S. (2007) Manejo de Plantas Daninhas Através de Métodos Alternativos ao Método Químico. In: Martin, T.N. and Montagner, M.M., Ed., Sistemas de Produção Agropecuária. UTFPr, Dois Vizinhos, 26-44.

[4] Heap, I. (2014) The International Survey of Herbicide Resistant Weeds. http://www.weedscience.org/In.asp 
[5] Vargas, L., Ulguim, A.R., Agostinetto, D., Dal-Magro, T. and Thurmer, L. (2013) Low Level Resistance of Goosegrass (Eleusine indica) to Glyphosate in Rio Grande do Sul-Brazil. Planta Daninha, 31, 677-686. http://dx.doi.org/10.1590/S0100-83582013000300019

[6] salton, J.C., Mercante, F.M., Tomazi, M., Zanatta, J.A., Concenço, G., Silva, W.M. and Retore, M. (2013) Integrated Crop-Livestock System in Tropical Brazil: Toward a Sustainable Production System. Agriculture, Ecosystems \& Environment, 190, 70-79. http://dx.doi.org/10.1016/j.agee.2013.09.023

[7] Brewin, D.G., Undi, M., Kulshreshtha, S., Wittenberg, K., Tenuta, M. and Ominski, K.H. (2014) Integration of Forage, Beef, and Hog Production Systems in Western Canada: An Economic Assessment. Agricultural Systems, 127, 1-8. http://dx.doi.org/10.1016/j.agsy.2013.12.005

[8] Afifi, M. and Swanton, C. (2012) Early Physiological Mechanisms of Weed Competition. Weed Science, 60, 542-551. http://dx.doi.org/10.1614/WS-D-12-00013.1

[9] Ceccon, G. (2013) Consórcio Milho-Braquiária. 1st Edition, Embrapa Western Agriculture, Dourados.

[10] Gulzar, A. and Siddiqui, M.B. (2014) Allelopathic Effect of Aqueous Extracts of Different Parts of Eclipta alba (L.) Hassk on Some Crop and Weed Plants. Journal of Agricultural Extension and Rural Development, 6, 55-60. http://dx.doi.org/10.5897/JAERD2013.0542

[11] Behringer, T., Lucht, W. and Schaphoff, S. (2010) Bioenergy Production Potential of Global Biomass Plantations Under Environmental and Agricultural Constraints. Global Change Biology Bioenergy, 3, 299-312. http://dx.doi.org/10.1111/j.1757-1707.2010.01088.x

[12] Caiazzo, F., Malina, R., Staples, M.D., Wolfe, P.J., Yim, S.H. L. and Barrett, S.R.H. (2014) Quantifying the Climate Impacts of Albedo Changes Due to Biofuel Production: A Comparison with Biogeochemical Effects. Environmental Research Letters, 9. http://dx.doi.org/10.1088/1748-9326/9/2/024015

[13] Chammoun, N. (2009) Properties, Performance, and Economics of Raphanus sativus (Oilseed Radish) Biodiesel. MSc. Thesis, University of Georgia, Athens.

[14] Barbour, M.G., Burk, J.H., Pitts, W.D., Gilliam, F.S. and Schwartz, M.W. (1998) Terrestrial Plant Ecology. 3rd Edition, Benjamin/Cummings, Menlo Park.

[15] Pandeya, S.C., Puri, G.S. and Singh, J.S. (1968) Research Methods in Plant Ecology. 1st Edition, Asia Publishing House, New York.

[16] MacManus, J.W. and Pauly, D. (1990) Measuring Ecological Stress: Variations on a Theme by R.M. Warwick. Marine Biology, 106, 305-308. http://dx.doi.org/10.1007/BF01314814

[17] Sneath, P.H. and Sokal, R.R. (1973) Numerical Taxonomy: The Principles and Practice of Numerical Classification. 1st Edition, W. H. Freeman, San Francisco.

[18] Sokal, R.R. and Rohlf, F.J. (1962) The Comparison of Dendrograms by Objective Methods. Taxon, 11, 33-40. http://dx.doi.org/10.2307/1217208

[19] R Core Team. (2014) R: A Language and Environment for Statistical Computing. http://www.R-project.org

[20] Bordeau, P.F. (1953) A Test of Random Versus Systematic Ecological Sampling. Ecology, 34, 499-512. http://dx.doi.org/10.2307/1929722

[21] Goldsmith, F.B. and Harrison, C.M. (1976) Description and Analysis of Vegetation. In: Chapman, S.B., Ed., Methods in Plant Ecology, John Wiley and Sons, New York, 85-155.

[22] Uygur, F.N., Koseli, F., Cnar, A. and Koch, W. (1990) The Allelopathic Effect of Raphanus sativus L. Journal of Plant Diseases and Protection, 12, 259-264.

[23] Severino, F.J., Carvalho, S.J.P. and Christoffoleti, P.J. (2005) Interferências Mútuas Entre a Cultura do Milho, Espécies Forrageiras e Plantas Daninhas em um Sistema de Consórcio. I. Implicações Sobre a Cultura do Milho (Zea mays). Planta Daninha, 23, 589-596. http://dx.doi.org/10.1590/S0100-83582005000400005

[24] Putnan, A.R. and DeFrank, J. (1983) Use of Phytotoxic Plant Residues for Selective Weed Control. Crop Protection, 2, 173-181. http://dx.doi.org/10.1016/0261-2194(83)90042-X

[25] Pitelli, R.A. and Pitelli, R.L.C.M. (2008) Controle Biológico de Plantas Daninhas na América Latina. In: Alves, S.B. and Lopes, R.B., Eds., Controle microbiano de pragas na América Latina, Vol. 1, Fealq, Piracicaba, 333-350.

[26] Mas, M.T., Verdú, A.M.C., Kruk, B.C., Abelleyra, D., Guglielmini, A.C. and Satorre, E.H. (2010) Weed Communities of Transgenic Glyphosate-Tolerant Soyabean Crops in Ex-Pasture Land in the Southern Mesopotamic Pampas of Argentina. Weed Research, 50, 320-330.

[27] Inderjit and Mallik, A.U. (2002) Chemical Ecology of Plants: Allelopathy in Aquatic and Terrestrial Ecosystems. 1st Edition, Springer, Basel.

[28] Correia, N.M. and Durigan, J.C. (2004) Emergência de Plantas Daninhas em Solo Coberto com Palha de Cana-deAçúcar. Planta Daninha, 22, 11-17. http://dx.doi.org/10.1590/S0100-83582004000100002 
Scientific Research Publishing (SCIRP) is one of the largest Open Access journal publishers. It is currently publishing more than 200 open access, online, peer-reviewed journals covering a wide range of academic disciplines. SCIRP serves the worldwide academic communities and contributes to the progress and application of science with its publication.

Other selected journals from SCIRP are listed as below. Submit your manuscript to us via either submit@scirp.org or Online Submission Portal.
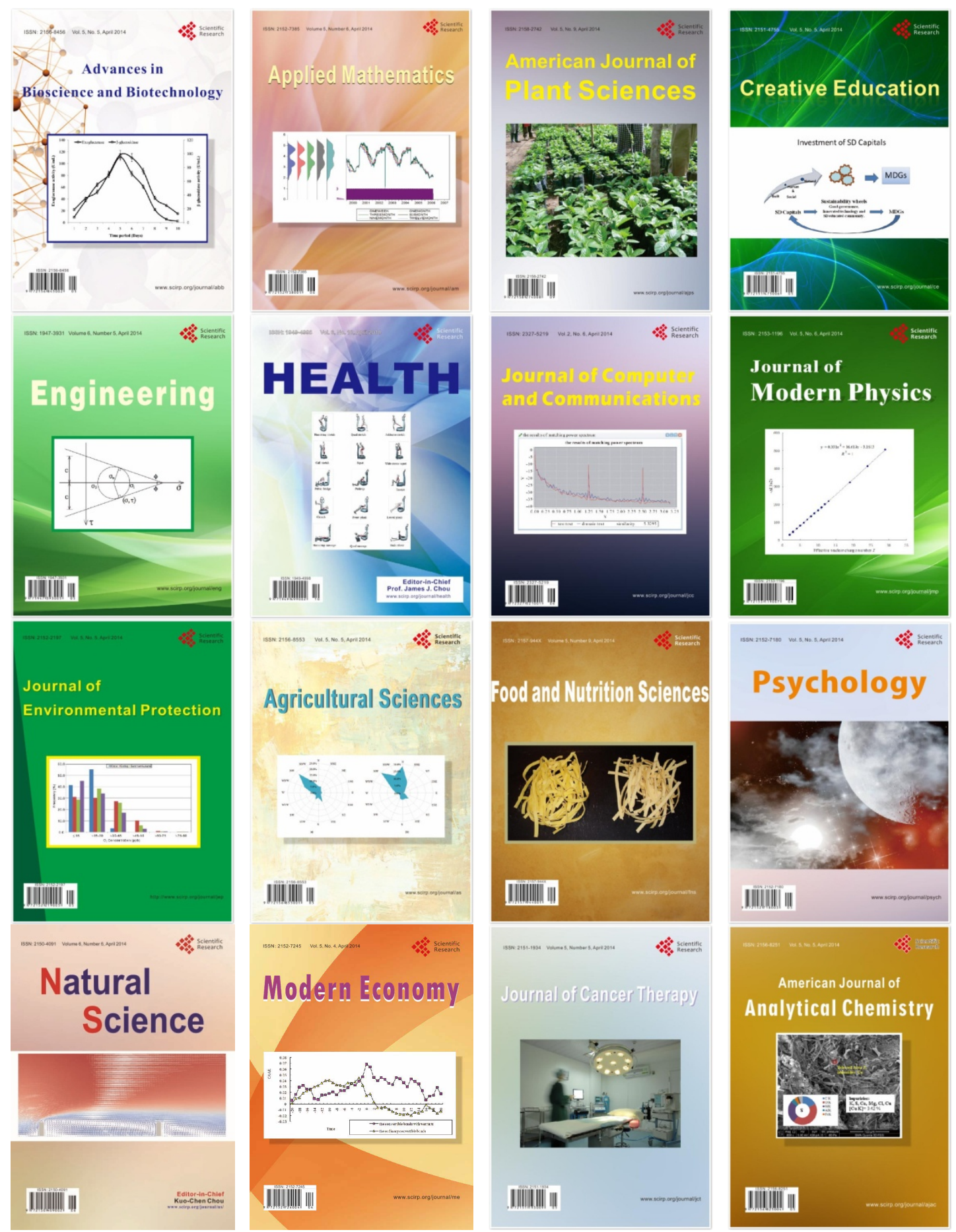